\title{
Opschorting overwinnen
}

De Academische wortels van Gassendi's probabilisme

\author{
Delphine Bellis
}

ANTW 108 (1): 99-120

DOI: 10.5117/ANTW2016.1.BELL

\begin{abstract}
Overcoming the Suspension of Assent: The Academic Roots of Gassendi's Probabilism

In this paper, I show that, beyond the role played by Pyrrhonian arguments in rebuking Aristotelian theses, Academic philosophy offered to Gassendi a probabilist model of knowledge which, contrary to the Pyrrhonian suspension of assent, opened the possibility of a natural philosophy conceived as a science of appearances. In addition to Gassendi's erudite interest for Cicero and Charron, Academic probabilism suited Gassendi's own practice as a natural philosopher in the realms of meteorology and astronomy. But first and foremost, Gassendi's preference for Academic philosophy rather than for Pyrrhonism was motivated, early in his philosophical career, by ethical concerns immanent to his practice of savant: the importance of preserving his libertas philosophandi for his experimental approach to nature, combined with his personal incapacity not to incline toward one opinion or another, led him to formulate his epistemological probabilism and to claim the freedom to revise his opinions from day to day.
\end{abstract}

Keywords: Pierre Gassendi, skepticism, Pyrrhonism, Academic philosophy, probabilism

In zijn History of Scepticism from Erasmus to Descartes ${ }^{1}$ argumenteert Richard Popkin dat een 'pyrronistische crisis' (crise pyrrhonienne) een belangrijke rol speelde bij het ontstaan van de filosofische moderniteit. Popkin zag deze filosofische crisis als een uitvloeisel van de religieuze crisis die voortkwam uit de Protestantse Reformatie. De crisis werd volgens hem 
gevoed door de herontdekking van de werken van Sextus Empiricus. Dit bracht Popkin ertoe de rol van een ander type antieke ondogmatische filosofie in de vorming van de vroegmoderne filosofie aanzienlijk af te zwakken, te weten het Academisch scepticisme.

Academisch scepticisme ontstond tegen de achtergrond van de door Plato gestichte Academie, voornamelijk onder zijn volgelingen Arcesilaus en Carneades, en was gebaseerd op de uitspraak van Socrates: 'Ik weet slechts dat ik niets weet.' Op theoretisch vlak, waarop ik mij hier zal concentreren, beweerden Academische sceptici dat zekere kennis van de werkelijkheid niet mogelijk is, maar dat het wel haalbaar is, althans volgens Carneades, om tot waarschijnlijke kennis ( $\pi \bullet \theta$ avóv) te komen. Verder waren zij van mening dat er enkele graden van waarschijnlijkheid zijn die afhangen van het soort bevestiging dat via zintuiglijke waarneming verkregen kan worden. Deze opvattingen werden vooral verspreid door Cicero, Augustinus en Diogenes Laërtius.

Pyrronisten daarentegen stonden een radicalere opvatting voor. Zij weigerden zelfs de stelling aan te nemen dat niets met enige zekerheid gekend kan worden. Zij pleitten voor oordeelsopschorting en voor een ononderbroken zoektocht naar waarheid. Deze vorm van scepticisme werd voornamelijk verspreid via de werken van Sextus Empiricus. In zijn reconstructie van de rol van het pyrronisme bij het ontstaan van de vroegmoderne filosofie schreef Popkin een cruciale rol toe aan Pierre Gassendi (evenals aan Marin Mersenne). Popkin onderscheidde in Gassendi's denken twee verschillende fasen: als eerste een pyrronistische periode en ten tweede een episode die Popkin 'gematigd scepticisme' noemde en die hij beschrijft als een soort reactie van Gassendi bedoeld om zijn vroege pyrronistische opvatting te overwinnen. Hiervan uitgaande verdeelde Popkin zijn analyse van Gassendi's filosofie over twee hoofdstukken in zijn boek. In het hoofdstuk over de 'libertins érudits" ${ }^{2}$ beschouwde hij Gassendi als een Pyrronist, op basis van diens eerst gepubliceerde werk, de Exercitationes paradoxicae adversus Aristoteleos (1624). Vervolgens wijdde hij een volgend hoofdstuk aan Gassendi's constructief scepticisme uit de latere periode van zijn Syntagma philosophicum (1658). ${ }^{3}$

In dit essay wil ik ingaan tegen Popkins visie, met name tegen zijn in mijn ogen te sterke nadruk op het pyrronisme. Ik zal laten zien dat het Academisch scepticisme voor Gassendi, al vroeg in zijn carrière, een alternatief bood voor de pyrronistische oordeelsonthouding. Tevens leverde het 
een model van kennis dat, in tegenstelling tot het pyrronisme, de mogelijkheid bood tot de vorming van een probabilistische natuurfilosofie. ${ }^{4}$

Het is niet mijn bedoeling te ontkennen dat pyrronistische argumenten een rol speelden in de aanval op en de verwerping van aristotelische opvattingen in Gassendi's Exercitationes paradoxicae. ${ }^{5} \mathrm{Ik}$ wil echter betogen dat er, naast deze louter negatieve of polemische functie van het pyrronisme, nog een ander type ondogmatische filosofie, namelijk het Academisch scepticisme, positief werkzaam was in de uitwerking van Gassendi's eigen filosofie, met inbegrip van de Exercitationes. Reeds in dit vroege werk maakte Gassendi een duidelijk onderscheid tussen het pyrronisme en het Academisch scepticisme. Hij stelde het pyrronisme gelijk met het scepticisme in eigenlijke $\operatorname{zin}^{6}$, dat volgens hem gekenmerkt werd door oordeelsopschorting. ${ }^{7}$ Om deze reden onderscheidde hij Academisch scepticisme van scepticisme in strikte zin. In dit essay zal ik laten zien hoe het probabilisme van de Academici geïntegreerd werd in Gassendi's epistemologie met als doel de pyrronistische oordeelsonthouding te overwinnen.

Maar behalve licht te werpen op de rol die het Academisch scepticisme speelde op dit theoretische vlak wil ik ook laten zien dat Gassendi's keuze voor het probabilisme van de Academici niet zozeer samenhing met algemene ethische overwegingen maar meer met een ethische dimensie die immanent is aan en specifiek voor de praktijk van de 'savant'.

\section{Gassendi's interpretatie van de plaats van het Academisch scepticisme in de geschiedenis van de filosofie: een polemisch en constructief instrument}

Popkin stelt dat het gematigd scepticisme van Mersenne en Gassendi 'a type of epistemological Pyrrhonism' vormt. ${ }^{8}$ Niettemin lijkt de definitie die

\footnotetext{
4 Voor een bespreking van de rol die het Academisch scepticisme speelde in de vroegmoderne filosofie, zie Schmitt (1972); Giocanti (2013).

5 Bloch heeft geïdentificeerd wat hij 'fake Pyrrhonism' noemt in de Exercitationes; zie Bloch (1971: 91-92). Brundell heeft ook de anti-aristotelische, en bijgevolg instrumentele, dimensie van Gassendi's zogenoemde pyrronisme opgemerkt; zie Brundell (1987: 27). Toch is Brundell er, in tegenstelling tot Bloch, niet in geslaagd de constructieve bijdrage van het Academisch scepticisme aan de vorming van Gassendi's eigen epistemologie op te merken. Over Gassendi's gebruik van sceptische argumenten, zie Walker (1983).

6 Zie Gassendi (1658, I: 72b).

7 Zie Gassendi (1658, I: 13b).

8 Popkin (2003: 94).
} 
Popkin gaf van gematigd scepticisme veel meer in de buurt te komen van Carneades dan van Pyrrho:

Another way of meeting the sceptical crisis was the formulation of a theory which could accept the full force of the sceptical attack on the possibility of human knowledge, in the sense of necessary truths about the nature of reality, and yet allow for the possibility of knowledge in a lesser sense, as convincing or probable truths about appearances. ${ }^{9}$

Hoewel Popkin terloops een overeenkomst opmerkt tussen deze vorm van scepticisme en Carneades' gedachtegoed, heeft hij nergens geprobeerd zijn opvatting te ondersteunen met behulp van tekstvergelijkingen. Mijn bedoeling is te laten zien dat de filosofie van de Academici een belangrijke bijdrage heeft geleverd aan de uitwerking van Gassendi's eigen filosofie. Om te beginnen zal ik twee onderbelichte aspecten van de aanwezigheid van de Academische filosofie in Gassendi's werken bespreken. Het eerste betreft de manier van argumenteren die Gassendi in de Exercitationes gebruikt. Het tweede aspect gaat over de genealogie van de Academische filosofie die Gassendi, als filosofiehistoricus, schetste en die hem in staat stelde zijn eigen filosofie te positioneren binnen de geschiedenis van de wijsbegeerte als een nieuwe middenweg tussen dogmatisme en scepticisme.

Het staat buiten kijf dat Gassendi veelvuldig gebruik maakte van pyrronistische argumenten in zijn eerste boek, de Exercitationes paradoxicae adversus Aristoteleos, waarvan het eerste gedeelte gepubliceerd werd in 1624. Om de aristotelici te weerleggen deed hij vooral een beroep op argumenten van Sextus Empiricus (bijvoorbeeld over de onmogelijkheid te vertrouwen op de zintuigen om tot objectieve kennis van de werkelijkheid te komen, geïllustreerd met de welbekende voorbeelden als de boot en de relativiteit van beweging, de gebroken stok en de vierkante toren). ${ }^{10}$ Ook maakte hij gebruik van argumenten van Diogenes Laërtius (over Pyrrho's tien modi). ${ }^{11}$ Daarnaast deed Gassendi beroep op argumenten uit Cicero's Academica, in het bijzonder op argumenten gericht tegen de aristotelische $^{12}$ en de Stoïsche dialectiek. ${ }^{13}$ In de gevallen waarin hij deze sceptische

9 Popkin (2003: 112) (mijn cursivering).

10 Zie Exercitationes, II, v, 1, in Gassendi (1658, III: 182b). Voor de voorbeelden van de gebroken stok en de vierkante toren, zie Sextus' Principes van het pyrronisme, I, 14. Het voorbeeld van de boot in beweging staat in zijn Tegen de mathematici, I (414).

11 Zie Exercitationes, II, vi, 2, in Gassendi (1658, III: 193a-195a).

12 Zie Exercitationes, II, i, 5, in Gassendi (1658, III: 152b-153a).

13 Zie Exercitationes, II, i, 8, in Gassendi (1658, III: 155b). 
argumenten in stelling bracht maakte Gassendi geen expliciet onderscheid tussen pyrronisme en Academisch scepticisme (ook al was hij zich terdege bewust van de verschillen, zoals we hieronder zullen zien).

Er is echter een meer specifieke manier waarop Cicero, als vertegenwoordiger van het Academisch scepticisme, bruikbaar was voor Gassendi's aanval op de aristotelische filosofie. In het voorwoord bij zijn Exercitationes wees Gassendi zijn lezer op de methode die hij gebruikte toen hij zijn studenten in Aix-en-Provence aristotelische filosofie onderwees en die hij opnieuw aanwendde in deze tekst. Deze methode bestond erin dat de wijzen van argumenteren pro et contra tegen de aristotelici gekeerd werd door deze methode terug te voeren op Aristoteles zelf en door tegelijkertijd een methode uit de retorica om te vormen tot een bijna sceptische manier van redeneren:

Door deze methode werden mijn leerlingen namelijk gewaarschuwd om niets ongegrond te verkondigen, door in te zien dat er geen enkele stelling of opvatting is, hoe geaccepteerd en welluidend ook, waarvan niet kan worden aangetoond dat het tegendeel net zo waarschijnlijk is, of vaak zelfs nog waarschijnlijker. En daarbij heb ik daadwerkelijk gemeend Aristoteles op dit punt beter te imiteren dan zijn gezworen volgelingen doen [...]. Maar zoals Cicero aantoont in zijn De oratore, 'heeft Aristoteles zijn jonge leerlingen er zelf in geoefend een these niet droog, op de manier van de filosofen, uiteen te zetten, maar in de gedragen stijl van de retorici, zowel voor als tegen redenerend, zodat er sierlijker en rijkelijker gesproken kon worden.14

Gassendi interpreteerde de zinsnede 'in utramque partem' niet alleen als een aanduiding van een retorische oefening, maar ook in epistemologische zin als een manier om tegengestelde opvattingen af te wegen, die eenzelfde mate van waarschijnlijkheid bleken te hebben, of zelfs als een manier om de meest waarschijnlijke opvatting vast te stellen. Deze interpretatie gaat terug op Cicero, zoals John Glucker opmerkt: 'Cicero is our only source for this goal of the Academic procedure of arguing for and against as aiming at probabile or ueri simile in matters philosophical. ${ }^{15}$ In de Tusculanae disputationes voert Cicero de Academische werkwijze van argumenteren in utramque partem' terug op Socrates en Carneades ${ }^{16}$ en stelt hij op dit punt de Academici en de peripatetici aan elkaar gelijk. ${ }^{17}$ Het doel van

14 Gassendi (1658, III: 100).

15 Glucker (1995: 133).

16 Zie Cicero, Gesprekken in Tusculum, V, iv, 11 in Cicero (1980: 159-160).

17 Zie Cicero, Gesprekken in Tusculum, II, iii, 9 in Cicero (1980: 63-64). 
deze methode was om dogmatische opvattingen te weerleggen en te vervangen door waarschijnlijke uitspraken. Dit is precies wat ingezet wordt door Gassendi in zijn Exercitationes tegen de aristotelici en door Cicero in zijn dialoog Academica tegen de stoïcijnen. Kortom, niet zozeer waar het gaat om de inhoud van de Exercitationes, maar meer ten aanzien van de wijze van redeneren, claimde Gassendi eerder de Academische dan de pyrronistische methode te volgen.

In zijn latere Syntagma philosophicum ontwikkelde Gassendi een meer systematische kijk op de plaats van de Academische filosofie binnen de geschiedenis van de wijsbegeerte. In navolging van Sextus Empiricus ${ }^{18}$ onderscheidde hij drie belangrijke groepen in de Griekse scholen: de dogmatici, de acataleptici en de sceptici. Met de laatstgenoemde school, die gekenmerkt werd door oordeelsonthouding, bedoelde hij het pyrronisme, met de tweede de Academische filosofie zoals die gevormd was door Arcesilaus. ${ }^{19}$ Gassendi voerde het ontstaan van de verschillende Academies historisch en doctrinair terug op de eerste Academie, opgericht door Plato. Hij legde vooral nadruk op wat Carneades, de stichter van de derde Academie of de Academia nova, onderscheidde van Arcesilaus: 'Hij [Carneades] wordt algemeen erkend als grondlegger van de Nieuwe oftewel de Derde Academie, aangezien hij Arcesilaus' methode van filosoferen heeft gematigd door te stellen dat er in de dingen weliswaar geen zekerheid, maar wel waarschijnlijkheid wordt verkregen. ${ }^{20}$ Het was belangrijk voor Gassendi om het specifieke van Carneades' zienswijze te benadrukken, omdat precies de notie van 'waarschijnlijkheid' een cruciale rol zou gaan spelen in zijn eigen epistemologie. Hierdoor vestigde Gassendi de aandacht op een aantal filosofische ideeën die hij zelf zou gaan combineren in zijn epistemologie. Tevens plaatste hij zijn eigen filosofie aan het einde van een meervoudig vertakte historische lijn.

Verderop in de Syntagma behandelde Gassendi de vraag naar het criterium voor waarheid. Hij maakte grofweg een onderscheid tussen degenen die het bestaan van een dergelijk criterium accepteerden (de dogmatici) en degenen die het verwierpen. Tot deze laatste groep behoorden de sceptici, dat wil zeggen de pyrronisten. ${ }^{21}$ Maar Gassendi voegde ook de Academici

18 Zie Sextus Empiricus, Grondslagen van het scepticisme, I, 1 [4] in Sextus Empiricus (1996: 63). 19 Gassendi omschreef het op de volgende manier: 'Anderen echter, menen en verkondigen dat het ware van dien aard is, dat het noch aangetroffen, noch waargenomen kan worden; vandaar dat zij “acataleptici” worden genoemd, want zij menen dat alle dingen ondoorgrondelijk zijn.' Zie Gassendi (1658, I: 13b).

20 Gassendi (1658, I: 18b).

21 Voor deze gelijkstelling van de sceptici met de pyrronisten, zie Gassendi (1658, I: 72b). 
aan deze groep toe. ${ }^{22}$ Hoewel hij eerder de Academici van de sceptici had onderscheiden op het punt van de oordeelsonthouding, maakte hij ten aanzien van de vraag naar het waarheidscriterium geen verschil tussen pyrronisten en Academici. Gassendi merkte op dat Carneades niet opnieuw een waarheidscriterium introduceerde dat Arcesilaus weerlegd had, juist omdat Carneades nooit beweerd had waarheid te kunnen bereiken, maar enkel waarschijnlijkheid. ${ }^{23}$ Voor zowel de pyrronisten als de Academici moest een eventuee ${ }^{24}$ waarheidscriterium inderdaad van zodanige aard zijn dat het elke misvatting zou uitsluiten en zou leiden tot onfeilbare zekerheid, zodat een oordeel op een stevige manier en zonder angst voor dwaling geveld zou kunnen worden. ${ }^{25}$ Voor de pyrronisten en de Academici moest het criterium toegang geven tot de waarheid omtrent de dingen, oftewel tot hun eigenlijke natuur, en niet alleen tot hun verschijningsvorm, oftewel de manier waarop ze verschijnen aan ons.

Ten aanzien van zintuiglijke verschijnselen was volgens de pyrronisten en Academici geen criterium nodig: men kon vertrouwen op de zintuiglijke waarneming. Ze waren het er namelijk over eens dat twijfel niet van toepassing was op de manier waarop dingen aan ons verschijnen. Waarneming was echter geen criterium in strikte zin, omdat het verschijnen van de dingen, als subjectieve verschijning, zijn eigen criterium was. Aangezien het voor de pyrronisten en Academici onmogelijk was om binnen de zintuiglijke waarneming te onderscheiden wat tot het object en wat tot onze subjectiviteit behoort, verwees de waarneming op zichzelf naar niets anders dan naar onze subjectieve percepties, dat wil zeggen naar de manier waarop de dingen aan ons verschijnen. De waarneming gaf geen informatie over de verborgen 'ware aard' van de dingen. Met andere woorden, voor zowel de Academici als de pyrronisten kon de zintuiglijke waarneming geen waarheidscriterium zijn, omdat een dergelijk criterium zou moeten verwijzen naar iets wat buiten zichzelf ligt (de ware aard van de dingen, buiten onze subjectieve percepties). Als de waarneming een criterium zou

22 Zie Gassendi (1658, I: 72b).

23 Zie Gassendi (1658, I: 72b).

24 Let wel, Sextus Empiricus heeft verschijnselen genoemd als criterium: cf. Grondslagen van het scepticisme, I, 11 [21-24] in Sextus Empiricus (1996: 67-68). Maar hier bedoelt hij dat verschijnselen altijd beschouwd worden als waar in zichzelf, en niet voor zover zij indicatief zijn voor de realiteit van de dingen.

25 Gassendi (1658, I: 70a): 'Aangezien het criterium van dien aard moet zijn, dat er geen enkele onwaarheid aan ten grondslag ligt, maar dat het juist zekere en onfeilbare kennis veroorzaakt; van dien aard kan echter niet datgene zijn wat slechts bewijst dat iets waarschijnlijk is, aangezien het geen volledige geloofwaardigheid teweegbrengt en omdat daaraan dus alleen maar een wankele en vreesachtige instemming kan worden toegekend.' 
zijn, zou het juist een criterium moeten zijn om de ware aard van de dingen vast te stellen, niet de verschijningsvormen ervan. ${ }^{26}$

Dit alles is essentieel om te begrijpen hoe Gassendi zijn eigen filosofie voorstelde als een soort syncretistische reeks van doctrines, die in staat zou zijn de problemen op te lossen die specifiek zijn voor elk van de filosofische scholen (de problemen van hetzij de dogmatici, hetzij de sceptici). Gassendi presenteerde zijn eigen positie als een middenweg (via media) tussen de dogmatici, die een waarheidscriterium accepteerden, en de sceptici, onder wie hij hier iedereen schaarde die het bestaan van een dergelijk criterium afwees (en tot wie hij daarom ook de Academici moest rekenen). ${ }^{27}$ Gassendi aanvaardde het bestaan van een waarheidscriterium, waardoor het problematisch wordt om zijn filosofie 'gematigd scepticisme' te noemen, zoals Popkin doet. Deze aanname van een dergelijk criterium plaatst Gassendi nu juist, volgens zijn eigen maatstaven, buiten het kamp van de sceptici (waaronder, precies op dit punt, ook de Academici vallen). In de Syntagma philosophicum, gaf Gassendi duidelijk het bestaan van een dubbel criterium toe: 'Daarom is het zo dat er in ons een tweevoudig criterium onderscheiden kan worden; één op grond waarvan wij een teken kunnen onderscheiden, namelijk de zintuiglijke waarneming; het andere op grond waarvan wij juist iets dat verborgen is kunnen begrijpen door te redeneren; dat laatste is het verstand, het intellect of de rede. ${ }^{.28} \mathrm{De}$ verschijnselen, die zeker zijn in zichzelf, zijn tekens die het ons mogelijk maken om de oorzaken van de fenomenen af te leiden. Maar Gassendi bleef terughoudend ten aanzien van de vraag hoe verreikend zijn waarheidscriterium zou kunnen zijn, vooral op het gebied van de natuurwetenschappen waar, zoals we hieronder zullen zien, veel van de verklaringen die Gassendi uitwerkte slechts waarschijnlijk zouden blijven. ${ }^{29}$

26 Zie Gassendi (1658, I: 70a).

27 Gassendi (1658, I: 79b).

28 Gassendi (1658, I: 81b).

29 Gassendi (1658, I: 79b): 'En omdat zeker het grootste deel van de dingen die de dogmatici menen te weten, hun in feite onbekend is, zal zich in de fysica zeer vaak de gelegenheid voordoen dat we moeten verklaren dat we al blij mogen zijn als we niet de waarheid bereiken, maar dat wat waarschijnlijk is.' 


\section{Gassendi's probabilisme als erfenis van de} Academische filosofie: de epistemologische betekenis van de toepassing van de notie van 'waarschijnlijkheid' op de natuurfilosofie

\subsection{De humanistische achtergrond}

Gassendi moet zijn grondige kennis van de filosofie van de Academici te danken hebben gehad aan de humanistische opleiding die hij in de jaren twintig van de zeventiende eeuw begon en die hem de gelegenheid bood Cicero, Sextus Empiricus en Pierre Charron te lezen. ${ }^{30}$ Deze kennis was ongetwijfeld essentieel voor de ontwikkeling van zijn anti-aristotelisme. Daarom moet er vanuit chronologisch oogpunt op gewezen worden dat Gassendi's interesse in Academische filosofie voor het eerst werd ingegeven door zijn humanistische scholing. Zoals al vaak is benadrukt, kende de humanistische traditie een belangrijke plaats toe aan de retorica, waarbinnen de categorie van het waarschijnlijke van groot belang was. De mogelijkheid om deze categorie toe te passen op de natuurfilosofie kwam gaandeweg op, naast het sterker waarderen van ervaringskennis in vergelijking met zuivere logica. ${ }^{31}$ De scheidslijn tussen wetenschappelijke kennis, in de aristotelische zin van het woord, en waarschijnlijke overtuiging, tot dusver traditioneel beperkt tot het domein van de retorica en de ethiek, begon aldus te vervagen.

\subsection{Probabilisme in de meteorologie en astronomie}

De invoering van de notie van 'waarschijnlijkheid' in de natuurfilosofie werd ook ondersteund door het veelvuldige gebruik ervan in enkele specifieke gebieden zoals de meteorologie en de astronomie, waarvan Gassendi al vanaf 1618 een beoefenaar was. Al sinds Aristoteles had de meteorologie fenomenen behandeld die voorkomen tussen de oppervlakte van de aarde en de maan (zoals winden, regenbogen, sneeuw etc.). Aangezien dergelijke fenomenen zich bevonden in de sfeer van het ondermaanse, waar onregelmatige en episodische verschijnselen konden voorkomen, werden meteorologische fenomenen traditioneel beschouwd als tot op zekere hoogte contingent en daarom als ontsnappend aan een strikt noodzakelijke causale verklaring. ${ }^{32}$ 
Gassendi's relatie tot het probabilisme in de astronomie is enigszins gecompliceerder. Ongetwijfeld was het probabilisme een wijdverbreide epistemologische positie op het gebied van de astronomie. ${ }^{33} \mathrm{Al}$ vanaf de Oudheid hadden sterrenkundigen geprobeerd om verklarende kosmologische modellen te construeren als verklaring voor hun uiteenlopende observaties. Deze modellen hadden niet de zekerheid van een bewijs, omdat ze gebaseerd waren op observaties van verafgelegen objecten die ze probeerden samen te brengen binnen een min of meer coherent wiskundig systeem. Omdat meerdere berekeningen bleken te passen bij de observaties en omdat verschillende verklaringen konden worden gegeven voor dezelfde fenomenen, moesten deze een probabilistische of hypothetische status hebben. ${ }^{34}$ Gassendi sloot zeker op een of andere manier aan bij deze traditie, die wijdverbreid was sinds de tweede helft van de zestiende eeuw.

Maar Gassendi's geloof in een probabilistische epistemologie in de astronomie werd des te sterker in het licht van de veroordeling van Galilei in 1633. Hoewel Gassendi aan het begin van zijn carrière als sterrenkundige astronomische theorieën doorgaans realistisch interpreteerde (niet als louter mathematische modellen), tegen de achtergrond van de theorie van Copernicus, stelde hij na 1633 en vooral in zijn Syntagma philosophicum dat hij, ook al had het heliocentrische systeem een zekere mate van waarschijnlijkheid, niettemin de beslissing van de Kerk over deze kwestie accepteerde en dat hij de hypotheses van Tycho Brahe de meest waarschijnlijke en meest geschikte vond om 'de fenomenen te redden'. ${ }^{35}$ Ook al raakte Gassendi al in de jaren twintig van de zeventiende eeuw geïnteresseerd in de Academische filosofie en begon hij een probalistische epistemologie te ontwikkelen, niettemin werkte hij de notie van waarschijnlijkheid pas na 1633 verder uit op het gebied van de astronomie, waar hij stelde dat het niet méér mogelijk was om te bewijzen dat de aarde stilstond dan dat ze bewoog. ${ }^{36}$

33 Zie Shapiro (1983: 44-45); Duhem (1908); Grant (1962).

34 Zie Franklin (2001: 134-140). Voor een dergelijke voorstelling van astronomische hypothesen die vanuit natuurkundig oogpunt als ongeldig beschouwd worden en slechts bedoeld waren om voor berekeningen te gelden, zie Gassendi (1658, I: 265a).

35 Het idee om 'de fenomenen te redden' werd verwoord in zijn Institutio astronomica (1647): zie Gassendi (1658, IV: 25a). Zie ook zijn Syntagma philosophicum in Gassendi (1658, I: 615a, 617b, 630a). Over Gassendi's verschuiving van een realistische naar een hypothetische benadering van astronomie en van een Copernicaanse naar een Tychonische kosmologie na de veroordeling van Galilei in 1633, zie Brundell (1987: 30-47).

36 Zie Gassendi (1658, I: 630a). 
Het is veelzeggend dat Gassendi, voor zover ik weet, de hypothesen van de sterrenkundigen nergens 'ficties' (fictio, figmentum) noemde vóór 1633 en dat hij ná 1633 deze verwijzing naar hypothetische verklaringen in de astronomie zelfs uitbreidde naar andere gebieden van de natuurfilosofie. Zo vergeleek Gassendi in een brief aan Mersenne uit 1635 de fictie of hypothese (wat voor hem vrijwel hetzelfde is) van een ondeelbaar mathematisch punt dat niet in werkelijkheid bestond in de natuur met de hypothesen die de sterrenkundigen gebruikten om hun berekeningen mee te maken. ${ }^{37}$ In 1646 trok Gassendi in zijn De proportione een parallel tussen de status van zijn verklaringen over vallende lichamen en de hypothesen van sterrenkundigen. ${ }^{38}$ Het moet echter worden opgemerkt dat, waar wiskundige modellen in de Antieke astronomie beschouwd werden als louter hypothesen of ficties, Gassendi's uitbreiding van probabiliteit buiten het beperkte domein van de astronomie naar het geheel van de natuurwetenschappen, ook betekende dat probabiliteit meer als een benadering van de werkelijkheid gezien ging worden dan alleen als wiskundig model. Het feit dat een verklaring getoetst moest worden aan de zintuiglijke ervaring bewees dat het geen pure fictie was. ${ }^{39}$

\subsection{De ontwikkeling van een probabilistische natuurwetenschap van zintuiglijke verschijnselen in Gassendi's epistemologie}

\subsubsection{Een wetenschap van verschijnselen}

$\mathrm{Al}$ in de Exercitationes paradoxicae pleitte Gassendi voor 'een bepaalde kennis, die op ervaring berust en dingen betreft die zich voordoen'. ${ }^{40}$ Verderop in zijn tekst voegde hij hieraan toe: 'het is mogelijk dat er gronden voor wetenschap zijn; maar alleen voor wetenschap die berust op de ervaring en die, om zo te zeggen, "wetenschap van de verschijnselen" is, aangezien ons intellect veel dingen die zich voordoen kent of leert kennen door ze te ervaren. ${ }^{41}$ Dit programma zou pas later gerealiseerd en volledig uitgewerkt worden in de Syntagma philosophicum. In tegenstelling tot de pyrronisten meende Gassendi dat het mogelijk was kennis te verkrijgen die verder reikt dan de verschijnselen en dat men kon proberen hun oor-

37 Zie Gassendi (1658, VI: 81b).

38 Zie Gassendi (1658, III: 635a).

39 Gassendi, Syntagma philosophicum, Institutio logica, I, Canon XI, in Gassendi (1658, I: 96b): 'ervaring verkregen via de zintuigen zou de hoogste maatstaf moeten zijn om toevlucht tot te nemen, als er getwijfeld wordt over een of andere zaak ...'

40 Exercitationes, II, vi, 1, in Gassendi (1658, III: 192a).

41 Exercitationes, II, vi, 7 in Gassendi (1658, III: 207a). 
zaken te achterhalen. Hierin toonde hij zich opnieuw erfgenaam van de Academische filosofie, omdat hij niet meende dat men moest vertrouwen op de verschijnselen als zodanig. Zijn notie van 'experiment' is in overeenstemming met de Academische opvatting van 'geïnspecteerde' of 'onderzochte' verschijnselen. ${ }^{42}$ Volgens Gassendi konden verschijnselen dus vanuit twee verschillende gezichtspunten bekeken worden en zo leiden tot twee verschillende niveaus van zekerheid. Ten eerste kon gekeken worden naar de manier waarop het object zich voordoet, of verschijnt, aan de waarnemer; in dit geval waren verschijnselen altijd volkomen zeker. Ten tweede konden verschijnselen gezien worden als gerelateerd aan het externe object, d.w.z. als een criterium om de oorzaken van de fenomenen te achterhalen ${ }^{43}$; zo werden de verschijnselen onderworpen aan een proces van stabilisering, dat twijfel zou wegnemen. In de Syntagma philosophicum maakte Gassendi expliciet wat hij precies verstond onder 'experimenteren met verschijnselen'. Het bestond er hoofdzakelijk in de verschijnselen te laten variëren om zo alle mogelijke obstakels uit de weg te ruimen (zoals obstakels die te maken hebben met afstand, beweging of medium) ${ }^{44}$ Door middel van dit proces werd het mogelijk om bepaalde eigenschappen aan dingen toe te schrijven en om zintuiglijke ervaring in relatie tot objectiviteit te redden van radicale twijfel.

Wat de filosofie van Carneades onderscheidde van het pyrronisme, was dat Carneades dacht dat het mogelijk was om een onderscheid te maken tussen meer en minder waarschijnlijke fenomenen, door ze met elkaar te vergelijken en aan elkaar te relateren, en door op basis daarvan enkele waarschijnlijke gevolgen ten aanzien van de dingen af te leiden. Fenomenen waren niet slechts geïsoleerde representaties, gelijkwaardig in termen van waarschijnlijkheid en onwaarschijnlijkheid, maar ze konden door de waarnemer met elkaar vergeleken en aan elkaar gerelateerd worden, zodat

42 Sextus Empiricus, Grondslagen van het scepticisme, I, 33 [227], in Sextus Empiricus (1996: 107): '[Z]ij [de academici] beweren dat sommige [voorstellingen] ongeloofwaardig zijn en andere geloofwaardig. / Ze maken ook onderscheid in de geloofwaardige voorstellingen. Sommige vinden

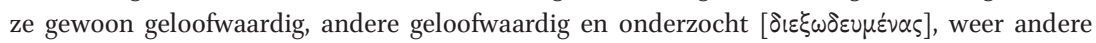
geloofwaardig, grondig onderzocht [ $\pi \varepsilon p ı \delta \varepsilon u \mu \varepsilon \dot{\varepsilon} \alpha \varsigma]$ en onbetwistbaar.' De eerste komen overeen met wat op het eerste gezicht lijkt; de tweede met wat door nader onderzoek blijkt; de derde met wat geconcludeerd kan worden door verschijnselen middels de rede te verbinden aan wat men al weet.

43 Syntagma philosophicum, Institutio logica, I, Canon XI in Gassendi (1658, I: 96b).

44 Gassendi, Syntagma philosophicum, Institutio logica, IV, Canon IV, in Gassendi (1658, I: 122a). 
ze op een meer of minder waarschijnlijke manier konden verwijzen naar dingen in de werkelijkheid. ${ }^{45}$ Dit is precies wat Gassendi als sterrenkundige deed: het verzamelen van verschillende hemelverschijnselen van hetzelfde fenomeen, op verschillende tijdstippen, vanuit verschillende plaatsen (via zijn imposante netwerk van correspondenten), deze vergelijken en op basis daarvan een soort objectieve verschijning proberen vast te stellen, die verklaard kon worden in termen van een meer of minder waarschijnlijke theorie. ${ }^{46}$

\subsubsection{De epistemologische status van het waarschijnlijke}

Gassendi gaf een nadere epistemologische uitwerking van de opvatting van het aannemelijke of waarschijnlijke, die hij grotendeels overgenomen had van de Academische filosofie, op een manier die van cruciaal belang was voor zijn fysica. Zelfs in zijn laatste werk Syntagma philosophicum bleef hij voorzichtig over de mogelijkheid om met zekerheid de ware aard van alle dingen te kennen, vooral binnen de fysica. De moeilijkheid was precies om binnen de wetenschap van de natuurlijke oorzaken het niveau van het slechts waarschijnlijke te ontstijgen, omdat het enige dat onmiddellijk zeker was, zintuigelijke ervaringen waren, die beschouwd werden als louter verschijnselen, onafhankelijk van hun relatie tot een object. Het formuleren van causale verklaringen van fenomenen komt evenwel neer op het overschrijden van de drempel van de zintuiglijke ervaring. Zorgvuldig onderzochte verschijnselen waren weliswaar niet misleidend, maar datgene wat op een algemener niveau uit deze verschijnselen kon worden afgeleid bleef onderhevig aan een vorm van relatieve onzekerheid. We hebben immers geen directe toegang tot de ware aard van de dingen die de fenomenologische verschijnselen veroorzaakten. Tevens zouden we morgen al nieuwe fenomenen kunnen ervaren, die niet meer verklaard zouden kunnen worden met de causale mechanismen die we op grond van eerdere ervaringen uit de natuurlijke dingen zouden hebben afgeleid.

Het probabilisme van Gassendi mag echter niet begrepen worden in een wiskundige of statistische zin. Zijn opvatting van het waarschijnlijke was kenmerkend voor een natuurfilosofie gebaseerd op verschijnselen,

45 Sextus Empiricus verwierp de verschillen die door de Academici geformuleerd waren tussen meer of minder waarschijnlijke verschijnselen, voor zover die werden vergeleken met en gerelateerd aan datgene waarvan zij de verschijningsvormen waren. Volgens hem waren alle verschijnselen 'aequipollent', d.w.z. gelijk in termen van waarschijnlijkheid of onwaarschijnlijkheid. Cf. Grondslagen van het scepticisme, I, 33 [227] in Sextus Empiricus (1996: 107).

46 Over de manier waarop Gassendi zijn opvatting over het objectief verschijnen uitwerkte voor de ogenschijnlijke grootte van hemellichamen, zie Bloch 1971, 16-18. 
waarin fenomenen als subjectieve gebeurtenissen begrepen werden. De mate van probabiliteit is voor hem afhankelijk van de psychologische kracht van een overtuiging. Het woord 'probabilis' betekent niets anders dan 'aannemelijk', 'overtuigend' of 'waarschijnlijk'. Met andere woorden, wat de Academici en Gassendi als 'waarschijnlijk' kwalificeren, impliceert niet een grotere of kleinere kans om het geval te zijn of om daadwerkelijk te gebeuren in de werkelijkheid. Het waarschijnlijke is niet gebaseerd op een waargenomen frequentie, maar heeft betrekking op het effect dat een propositie teweegbrengt op psychologisch niveau. Daarom bracht Gassendi's empirisme hem niet tot een statistische opvatting van probabiliteit, gebaseerd op het herhaaldelijk waarnemen van natuurlijke fenomenen. In plaats daarvan bleef hij trouw aan de Academici uit de Oudheid, en wel omdat zijn opvatting van het waarschijnlijke nog steeds afhankelijk is van een overwegend psychologische benadering.

Toch was er een belangrijk verschil tussen de opvatting van Gassendi en die van Carneades over het waarschijnlijke, omdat de manier waarop Gassendi de opvatting van de Academici over het waarschijnlijke gebruikte, bemiddeld was door Cicero. Gassendi erkende dat Carneades waarschijnlijke representaties gebruikt had als criterium in het praktische domein van het menselijk handelen. ${ }^{47}$ Maar het was Cicero die deze opvatting had geïntroduceerd in het theoretische domein. ${ }^{48}$ Gassendi volgde in zijn eigen kennistheorie eerder Cicero dan Carneades. Hij hevelde het criterium van verschijning dus over van de ethiek naar natuurfilosofie. Dit betekent evenwel niet dat Gassendi eenvoudigweg het gebruik van de opvatting van het waarschijnlijke uit de ethiek transponeerde naar de natuurfilosofie, door het simpelweg te ontdoen van zijn ethische dimensie. De ethische dimensie ging juist deel uit maken van de activiteit van de natuurfilosoof; het werd een soort ethos. 


\section{$3 \quad$ Academische filosofie als bron voor Gassendi's opvatting van het ethos van de filosoof}

In het voorwoord van de Epistolica exercitatio (1630) gericht aan Mersenne reageerde Gassendi op de kritiek van zijn vriend dat hij een pyrronist zou zijn, door een beroep te doen op het idee van een manier van leven:

Want hoewel u mij bijna verbiedt pyrronist te zijn en me zo steeds onder druk zet, alsof ik iets op dogmatische wijze naar voren zou kunnen brengen, moet $u$ mij op uw beurt, volgens de wetten van de vriendschap, de vrijheid gunnen om van dag tot dag te leven en nooit iets naar buiten te brengen of aan te nemen dat de grenzen van pure waarschijnlijkheid te buiten gaat. ${ }^{49}$

Merk op dat Gassendi hier niet zelf beweert pyrronist te zijn, maar dat hij slechts de kritiek van Mersenne weergeeft. Al in 1621 distianteerde Gassendi zich van het pyrronisme, in een brief aan Henri du Faur de Pibrac. Dit deed hij vooral om ethische redenen en hier verwijst hij al naar een leven van dag tot dag:

Toch was ik nooit zozeer een pyrronist dat mijn verlangen me er niet bijna toe bewoog met de andere partij in te stemmen. Het enige wat mij blijkbaar ontbrak om met Sextus Empiricus te wedijveren, was ervaring ( $\left.\dot{\varepsilon} \mu \tau \varepsilon ı \rho^{\prime} \alpha\right)$. Daarop legde ik mij in het verleden toe. Nu echter leg ik mij er volledig op toe om van dag tot dag te leven en me nooit te gedragen alsof ik me te houden heb aan verzegelde standpunten. ${ }^{50}$

Ook al had Gassendi zich in zijn jeugd aangetrokken gevoeld tot het pyrronisme, deze brief toont aan dat deze stroming al vanaf 1621 geen echte filosofische optie meer voor hem was. ${ }^{51}$ Het pyrronisme stond een ideaal van wijsheid voor dat voor Gassendi onmogelijk leek te zijn om na te leven (hoewel het op theoretisch niveau bruikbaar kon zijn), omdat hij altijd de neiging had om één positie te verkiezen boven de andere. Pyrronisme, met zijn vereiste opschorting van elk oordeel, bracht met zich mee dat weerstand geboden moest worden tegen deze niet te onderdrukken neiging van het verstand. Dit zou klaarblijkelijk te veel psychologische druk uitgeoe-

49 Gassendi (1658, III: 214).

50 Gassendi aan Henri du Faur de Pibrac, 8 april 1621 in Gassendi (1658, VI: 1b).

$5^{1}$ Zelfs al had Gassendi ooit een soort neiging tot pyrronisme gehad, zijn verwerping ervan dateert klaarblijkelijk al van vóór het schrijven van de Exercitationes paradoxicae en kan daarom niet Popkin's interpretatie ondersteunen. 
fend hebben op Gassendi. Academische filosofie daarentegen pleitte voor een leven van dag tot dag, wat niet betekende dat men zich (bij voorbaat) moest onthouden van een oordeel, maar dat men kon instemmen met wat op de ene dag het meest waarschijnlijk leek, terwijl de volgende dag met iets anders ingestemd kon worden. Het is veelzeggend dat in dezelfde brief aan Du Faur de Pibrac Gassendi Cicero en Pierre Charron prijst als pleitbezorgers van de Academische filosofie. ${ }^{52}$ Cicero pleitte namelijk voor een vrijheid van filosofie-beoefening, een 'libertas philosophandi', die voor hem hand in hand ging met zijn aanvaarding van de Academische filosofie. We zien dit in Boek V van zijn Tusculanae Disputationes, waar Gassendi impliciet naar verwees in zijn brief aan Du Faur de Pibrac en in zijn Epistolica exercitatio. ${ }^{53}$ In de Exercitationes paradoxicae maakte hij de verwijzing expliciet:

Zeker getuigt hij van meer wellevendheid, die zegt: 'Wij zijn in die zin vrijer en ongebondener, dat wij de volledige beschikking over ons oordeelsvermogen hebben, en dat we niet door die noodzakelijkheid gedwongen worden alles te verdedigen wat is voorgeschreven en als het ware is bevolen. De anderen worden namelijk al stevig gekneveld voordat zij zelfs maar in staat zijn te beoordelen wat het beste zou kunnen zijn. En vervolgens vellen zij, nog op een uiterst kwetsbare leeftijd, doordat zij ofwel meegaan met een toevallige vriend ofwel in de ban zijn geraakt van de woorden van iemand naar wie ze als eerste geluisterd hebben, oordelen over zaken die ze niet kennen.' Deze man is natuurlijk Marcus Tullius [Cicero]. Toen iemand hem er een keer op gewezen had dat hij ervoor moest waken zijn standvastigheid prijs te geven, daar hij niet altijd dezelfde inzichten aanhield, zei hij: 'Je discussieert tegen me met de getekende stukken in de hand en haalt als getuige iets aan dat ik ooit eens heb gezegd of geschreven. Die methode is misschien goed tegenover anderen die volgens vastgestelde regels discussiëren. Wij leven bij de dag: wij zeggen alles wat ons verstand met waarschijnlijkheid heeft getroffen. En daarom zijn wij de enigen die vrij zijn. ${ }^{54}$

Gassendi's verwerping van het dogmatisme leek aanvankelijk gemotiveerd te zijn door zijn teleurstelling ten aanzien van de ethische dimensie van het aristotelisme, dat niet te rijmen was met het levensideaal dat door

$5^{2}$ Gassendi (1658, VI: 1b-2a).

53 Cicero, Gesprekken in Tusculum, V, xi, 33 in Cicero (1980: 168): 'Wij leven van de ene dag in de andere. Wij zeggen alles wat onze geest treft door zijn overtuigend karakter, en op die manier zijn wij de enigen die echt vrij zijn.'

54 Exercitationes, I, ii, 8 in Gassendi (1658, III: 113b). 
Cicero in verband gebracht was met filosofie. ${ }^{55}$ Het lijkt dus de ethische dimensie te zijn die Gassendi richting het anti-aristotelisme en de Academische filosofie bracht. Welnu, enkele regels voor het zojuist aangehaalde citaat uit de Exercitationes bracht Gassendi de libertas philosophandi in verband met de aanvaardig van het probabilisme, om zo nogmaals zijn pijlen te richten op de aristotelici, die deze libertas philosophandi ontkenden door zichzelf te onderwerpen aan de doctrine van hun leermeester:

Of moeten we die vrijheid soms niets waard achten? Maar zij die haar eens omarmden, hebben zich teruggetrokken in een heel veilige schuilplaats. Zij werken zich in elk geval niet meer in het zweet om die opvattingen te verdedigen die hun eerst zo bevielen, daar ze bereid zijn die net zo gemakkelijk los te laten als dat ze een gebalde vuist openen. Ze beseffen immers dat het menselijk verstand dermate zwak is dat het, wanneer het de dingen zelf niet werkelijk kan weten, daaromtrent slechts waarschijnlijke gissingen fabriceert. Daardoor komt het dat ze nooit iets met ernst en arrogantie verdedigen en denken dat Aristoteles niet minder gedwaald heeft dan Pythagoras of Plato, terwijl ze intussen in stilte en zonder enige verstoring van hun gemoedsrust nagaan welke van de tegengestelde opvattingen van de dogmatici het meest in de buurt van de waarheid komt. ${ }^{56}$

In deze passage tekent zich de methode af die Gassendi zelf zou gaan volgen in de Syntagma philosophicum. ${ }^{57}$ Gassendi stelde de notie 'libertas philosophandi', die hij van Cicero had geërfd, centraal als zijn filosofische motivatie. In tegenstelling tot het pyrronisme, dat tot opschorting van oordeel leidde, en bijgevolg ook tot een uitschakeling van het oordeelsvermogen, berustte de Academische filosofie op probabilisme en daarom ook op een voorlopige aanname van de zienswijze die het meest waarschijnlijk leek. Deze waarschijnlijkheden konden waar nodig van dag tot dag worden herzien.

Het idee van 'leven bij de dag' lijkt vooral verband te houden met ethiek. Vanuit ethisch perspectief zou een leven van dag tot dag ons in staat moeten stellen de toekomst te bezien met een soort innerlijke rust of onverstoorbaarheid. Inderdaad zijn wij op die manier erop ingesteld niet te veel belang te hechten aan onze theoretische en praktische over-

55 Zie het autobiografische relaas over Gassendi's filosofische roeping in het voorwoord van de Exercitationes paradoxicae: Gassendi (1658, III: 99).

56 Exercitationes, I, ii, 7 in Gassendi (1658, III: $113 \mathrm{~b})$.

57 Zie vooral het Liber Proemialis in Gassendi (1658, I: 3ob). 
tuigingen van vandaag de dag en ze te zien als onderhevig aan verandering. Zo zijn we erop voorbereid om te anticiperen op toekomstige gebeurtenissen die ons onze overtuigingen in twijfel doen trekken en ons dwingen deze te verlaten. Door onze overtuigingen als voorlopig te zien, zouden we de psychologische crises moeten kunnen voorkomen die samengaan met het opgeven van overtuigingen waar we te veel waarde aan hechten. ${ }^{58}$ Gassendi's ethiek ging inderdaad uit van het idee dat men zou mogen handelen op grond van waarschijnlijke kennis die van dag tot dag hierzien kon worden.$^{59}$ Een waarschijnlijke verklaring van fenomenen zou dus ook gekarakteriseerd kunnen worden door haar ethische dimensie: dit is wat de natuurfilosoof in staat stelt om zijn onderzoek tijdelijk te onderbreken en zijn verstand tevreden te stellen, zonder hem daarbij te dwingen tot dogmatisme, dat wil zeggen zonder hem te beroven van zijn vrijheid. Door voorlopig te neigen tot één bepaalde overtuiging nam de filosoof gematigde risico's, maar voor Gassendi was dit juist kenmerkend voor een authentieke filosofische houding. ${ }^{60}$ Wat nog typerender is voor Gassendi is de integratie van dit onderwerp binnen zijn epistemologie.

Door aan de van Cicero geërfde Academische notie van 'libertas philosophandi' een centrale plaats toe te kennen laat Gassendi zien hoeveel belang hij hechtte aan het behouden van de vrijheid om te oordelen. Hem is er meer aan gelegen het oordeelsvermogen te trainen dan om het op te schorten of uit te schakelen. Deze vrijheid om te oordelen was met name waardevol voor Gassendi, omdat zij essentieel was voor zijn eigen opvatting over de beoefening van de natuurfilosofie. Pyrronisme kon inderdaad tot niets meer leiden dan een verzameling van diverse en steeds veranderende verschijnselen, die inzicht in de ware aard van de dingen niet dichterbij bracht. Ook al vond Gassendi in de pyrronistische oordeelsonthouding een belangrijk middel om het aristotelische dogmatisme te overwinnen, als het aankwam op een poging de natuurlijke dingen te kennen en een natuurfilosofie te ontwikkelen, was het nodig oordelen te formuleren

$5^{8}$ Over Epicurus schreef Gassendi: 'Hij dacht dat de dingen die in het leven voorvallen weliswaar eveneens onderworpen zijn aan Fortuna, maar dat het het geschenk van de wijsheid is die dingen van hun scherpe kanten te ontdoen en de geest voor te bereiden op elke interventie van Fortuna' (Gassendi [1658, II: 830a]).

59 Zie Gassendi (1658, II: 821-825).

6o Zie zijn brief aan Thomas Fienus, 6 juni 1629, in Gassendi (1658, VI: 16b-17a): 'Want ik houd buitengewoon veel van die vrijheid om te filosoferen $[\ldots]$. Wat een schande is het dan dat zij die zich erop beroemen filosofen te zijn, niet de moed hebben zichzelf als mensen te beschouwen en bang te zijn dat ze, als ze niet op de wandelstok van een autoriteit kunnen leunen, onvast op hun voeten zullen staan, zullen gaan wankelen en op de grond zullen vallen!' 
die verder konden gaan dan enkel idiosyncratische verschijnselen. Het louter opschorten van een oordeel, zoals de pyrronisten deden, kon op geen enkele wijze de grondslag vormen om een fysica op te bouwen. Er waren op zijn minst voorlopige oordelen nodig om verschillende verschijnselen middels hun waarschijnlijke oorzaken met elkaar in verband te brengen. Maar deze oordelen moesten wel herzien kunnen worden. Voor zover Gassendi een fundamenteel empirische epistemologie voorstelde, was het essentieel voor hem dat de natuurfilosoof zijn theorieën moest kunnen herzien aan de hand van de verschillende resultaten die hij kon verkrijgen uit nieuwe ervaringen. De ware filosoof was degene die voortdurend nieuwe ervaringen zocht. In de Syntagma philosophicum beschreef Gassendi hem als volgt:

Hij is degene die niet debatteert op grond van autoriteit en evenmin met verwarrende omwegen of logische muggenzifterijen, maar louter met behulp van de eenvoudige, open rede en met een overvloed aan onbetwijfelbare en vaak bevestigde ervaringsgegevens; en zo wordt hij het nooit moe diep na te denken, onderzoek te doen en ongebaande paden te begaan. Hij stelt zich niet koppig op, maar slaat ook niet op de vlucht, noch wordt hij door schaamte bevangen als hij gedwongen wordt van mening te veranderen omdat hem iets is duidelijk gemaakt door iemand die niet eens een beroemd man hoeft te zijn, maar bijvoorbeeld ook een boer, een jongen of een vrouwtje zou kunnen zijn. In vol vertrouwen en met opgewektheid laat hij de minder waarschijnlijke opvatting varen en omarmt hij wat waarschijnlijker is $[\ldots] .{ }^{61}$

Het empirisme van Gassendi heeft zo het fundament gevormd voor zijn theorie van kennis door de tijd heen, want wij nemen op een bepaald moment en vanuit een bepaald perspectief dingen waar middels onze zintuigen, en zintuigelijke verschijnselen kunnen veranderen. Aangezien verschijnselen het enige zijn waar we zeker van kunnen zijn, was het van cruciaal belang het verwerven van kennis van nieuwe verschijnselen niet te voorkomen. Dit is nog een reden waarom de Academische filosofie een veel constructievere rol speelde in Gassendi's kennistheorie dan het pyrronisme. Zoals Howard T. Egan schrijft: '[T]o throw up one's hands in the despairing suspension of judgment may rule out a real possibility of future sense knowledge. ${ }^{62}$ Aangezien alle kennis op ervaring gebaseerd was en

61 Syntagma philosophicum, Liber prooemialis 'De philosophia universe,' IV in Gassendi (1658, I: 10a).

62 Egan (1984: 86). 
deels op inductie, en aangezien men er nooit zeker van kon zijn een volledige inductie ${ }^{63}$ te hebben uitgevoerd, moest iemands kennis open blijven voor falsificatie en kon er slechts een zeer zorgvuldige en voorlopige inductie worden toegepast. ${ }^{64}$ De kennis van de natuur werd een proces met een open einde en dus een historisch proces. Dit betekent dat de definitie van het ideaal van de ware filosoof niet alleen betrekking had op de vraag op welke manier een onverstoorbaarder of een gelukkiger leven bereikt kan worden. Natuurfilosofie werd door Gassendi gezien als activiteit die een bepaalde houding of een bepaald ethos veronderstelde, en niet alleen als de keuze tussen theoretische standpunten. Het kwam er niet alleen op aan om theoretische standpunten op rationele wijze te evalueren en daaruit de beste te kiezen, maar ook om een geesteshouding aan te nemen waarmee de filosoof en wetenschapper ontvankelijk kon blijven voor nieuwe feiten, nieuwe experimentele data kon verzamelen, nieuwe verklaringen kon uitwerken en zonodig eerder aangenomen verklaringen in twijfel kon trekken. Gassendi's filosofie kwam uiteindelijk dichter in de buurt van de Academische filosofie dan van het pyrronisme, omdat hij natuurfilosofie beschouwde als een activiteit met een niet te scheiden theoretische en ethische dimensie. ${ }^{65}$ Academische filosofie voorzag hem van een model van de deugden die nodig waren voor een juiste beoefening van natuurfilosofie.

Terwijl Cicero enkel tot het theoretische domein had uitgebreid wat Carneades beperkt had tot de praktijk, gaf Gassendi een veel complexere en rijkere invulling aan de opvatting van waarschijnlijkheid. Gassendi nam weliswaar de uitbreiding over die Cicero aan de notie 'waarschijnlijkheid' gegeven had, maar hij gaf er een specifiekere filosofische en epistemologische betekenis aan. In plaats van de opvatting slechts over te hevelen van het ene domein naar het andere, verwoordde Gassendi op een originele manier de theoretische en praktische dimensie van het aannemelijke of waarschijnlijke, afgeleid van het Griekse ' $\pi$ i $\theta$ avóv'. Het waarschijnlijke bestond niet alleen in datgene wat ons leidt in het dagelijks leven, maar het definieerde naast de epistemologische status van verklaringen binnen de natuurfilosofie ook een filosofische houding. In plaats van een permanente staat van ongerustheid op te wekken, was dit ethos erop gericht de filosoof

63 Zie Exercitationes paradoxicae, II, v, 5 in Gassendi (1658, III: 187b-188a).

64 Zie Syntagma philosophicum, Institutio logica, III, Canon XI, in Gassendi (1658, I: 113a).

65 In zijn Syntagma philosophicum verklaarde hij dat deugd voor hem niet slechts iets was dat behoorde tot het morele domein, maar ook tot de wetenschap en geleerdheid, voor zover deze laatste twee bedoeld waren om het verstand te verbeteren: zie Gassendi (1658, II: 705b). 
voor te bereiden op nog niet eerder waargenomen experimentele resultaten. Daarom is het essentieel om naast het intensieve, maar enigszins oppervlakkige gebruik van pyrronistische argumenten tegen het aristotelisme, zoals beschreven in de Exercitationes, Gassendi's gehele oeuvre in ogenschouw te nemen, om zo de invloed van de Academische filosofie op Gassendi opnieuw vast te stellen. Geen van de door Gassendi gepubliceerde werken getuigt van een pyrronistische crisis die aanleiding zou kunnen geven tot een verdenking van fideïsme. $\mathrm{Al}$ in 1621 beriep Gassendi zich op de Academische filosofie als bron die hem zou helpen bij het definiëren van zijn eigen epistemologische en de daarbij behorende ethische standaarden. ${ }^{66}$

\section{Bibliografie}

Bloch, O. (1971) La philosophie de Gassendi, Nominalisme, matérialisme et métaphysique. The Hague: Martinus Nijhoff.

Brundell, B. (1987) Pierre Gassendi. From Aristotelianism to a New Natural Philosophy. Dordrecht: Reidel.

Cicero (1980) Gesprekken in Tusculum. Vertaald door Cornelis Verhoeven. Baarn: Ambo.

Cicero (1956) De natura deorum. Academica. Latijn tekst en Engelse vertaling door R. Rackham. Cambridge MA: Harvard University Press.

Duhem, P. (1908) $\Sigma$ SZEIN TA ФAINOMENA. Essai sur la notion de théorie physique de Platon à Galilée. Paris: Hermann.

Egan, H.T. (1984) Gassendi's View of Knowledge. A Study of the Epistemological Basis of His Logic. Lanham: University Press of America.

Franklin, J. (2001) The Science of Conjecture. Evidence and Probability before Pascal. Baltimore: The Johns Hopkins University Press.

Gassendi, P. (1658) Opera omnia, 6 vols. Lyon: Anisson and Devenet.

Giocanti, S. (2013) La fécondité des Académiques de Cicéron dans l'Histoire du scepticisme, Astérion 11, http://asterion.revues.org/2334

Glucker, J. (1995) Probabile, Veri Simile, and Related Terms, in: J.G.F. Powell (red.) Cicero the Philosopher. Twelve Papers. Oxford: Clarendon Press, pp. 115-143

Grant E. (1962) Hypotheses in Late Medieval and Early Modern Science, Daedalus 91(3), pp. 599616.

Martin, C. (2011) Renaissance Meteorology: Pomponazzi to Descartes. Baltimore: The Johns Hopkins University Press.

66 Onderzoek voor dit artikel is mogelijk gemaakt door een Veni-subsidie (016.144.o11) gefinancierd door NWO. Ik wil graag Paul Bakker, Raphaël Chappé, Christoph Lüthy, Carla Rita Palmerino, Kuni Sakamoto, en Jan Willem Wieland bedanken voor hun behulpzame suggesties. Dit artikel is een ingekorte versie van een essay dat in het Engels is geschreven onder de titel 'Nos in Diem Vivimus: Gassendi and Academic Philosophy from Day to Day,' dat zal verschijnen in: Sébastien Charles and Plínio Junqueira Smith (red.), Academic Scepticism in Early Modern Philosophy, Dordrecht: Springer, International Archives of the History of Ideas. 
Popkin, R. (1960) The History of Scepticism from Erasmus to Descartes. Assen: Van Gorcum.

Popkin, R. (2003) The History of Scepticism from Savonarola to Bayle. Oxford: Oxford University Press.

Sextus Empiricus (1996) Grondslagen van het scepticisme. Vertaald door R. Ferwerda. Baarn/ Antwerpen: Ambo/Kritak.

Schmitt, C.B. (1972) Cicero Scepticus: a Study of the Influence of the Academica in the Renaissance. The Hague: Martinus Nijhoff.

Shapiro, B.J. (1983) Probability and Certainty in Seventeenth-Century England. A Study of the Relationships between Natural Science, Religion, History, Law, and Literature. Princeton: Princeton University Press.

Walker, R. (1983) Gassendi and Skepticism, in: M. Burnyeat (red.) The Skeptical Tradition. Berkeley: University of California Press, pp. 319-336.

\section{Over de auteur}

Delphine Bellis is postdoctoraal onderzoeker filosofie aan de Radboud Universiteit Nijmegen en lid van het Center for the History of Philosophy and Science. In 2010 behaalde ze haar doctorstitel cum laude in de filosofie aan de Radboud Universiteit en de Université Paris IV. Ze heeft meerdere artikelen gepubliceerd over de metafysica en fysica van Descartes. Dankzij een Veni-subsidie door NWO onderzoekt zij momenteel Gassendi's theorie van ruimte. 